\title{
A new interpretation of total column BrO during Arctic spring
}

\section{Citation}

Salawitch, R. J., T. Canty, T. Kurosu, K. Chance, Q. Liang, A. da Silva, S. Pawson, et al. 2010. "A New Interpretation of Total Column BrO During Arctic Spring." Geophys. Res. Lett. 37 (21) (November): n/a-n/a. doi:10.1029/2010gl043798.

\section{Published Version}

doi:10.1029/2010GL043798

\section{Permanent link}

http://nrs.harvard.edu/urn-3:HUL.InstRepos:14764378

\section{Terms of Use}

This article was downloaded from Harvard University's DASH repository, and is made available under the terms and conditions applicable to Other Posted Material, as set forth at http:// nrs.harvard.edu/urn-3:HUL.InstRepos:dash.current.terms-of-use\#LAA

\section{Share Your Story}

The Harvard community has made this article openly available.

Please share how this access benefits you. Submit a story.

\section{Accessibility}




\title{
A new interpretation of total column BrO during Arctic spring
}

\author{
R. J. Salawitch, ${ }^{1,2,3}$ T. Canty, ${ }^{1}$ T. Kurosu, ${ }^{4}$ K. Chance, ${ }^{4}$ Q. Liang, ${ }^{5}$ A. da Silva, ${ }^{6}$ \\ S. Pawson, ${ }^{6}$ J. E. Nielsen, ${ }^{7}$ J. M. Rodriguez, ${ }^{6}$ P. K. Bhartia, ${ }^{6}$ X. Liu, ${ }^{4,5}$ L. G. Huey, ${ }^{8}$ \\ J. Liao,${ }^{8}$ R. E. Stickel, ${ }^{8}$ D. J. Tanner, ${ }^{8}$ J. E. Dibb, ${ }^{9}$ W. R. Simpson, ${ }^{10}$ D. Donohoue,${ }^{10}$ \\ A. Weinheimer, ${ }^{11}$ F. Flocke, ${ }^{11}$ D. Knapp, ${ }^{11}$ D. Montzka, ${ }^{11}$ J. A. Neuman, ${ }^{12,13}$ \\ J. B. Nowak, ${ }^{12,13}$ T. B. Ryerson, ${ }^{13}$ S. Oltmans, ${ }^{13}$ D. R. Blake, ${ }^{14}$ E. L. Atlas, ${ }^{15}$ \\ D. E. Kinnison, ${ }^{11}$ S. Tilmes, ${ }^{11}$ L. L. Pan, ${ }^{11}$ F. Hendrick, ${ }^{16}$ M. Van Roozendael, ${ }^{16}$ \\ K. Kreher, ${ }^{17}$ P. V. Johnston, ${ }^{17}$ R. S. Gao, ${ }^{13}$ B. Johnson, ${ }^{13}$ T. P. Bui, ${ }^{18}$ G. Chen, ${ }^{19}$ \\ R. B. Pierce, ${ }^{20}$ J. H. Crawford, ${ }^{19}$ and D. J. Jacob ${ }^{21}$
}

Received 30 April 2010; revised 24 August 2010; accepted 27 August 2010; published 3 November 2010.

[1] Emission of bromine from sea-salt aerosol, frost flowers, ice leads, and snow results in the nearly complete removal of surface ozone during Arctic spring. Regions of enhanced total column $\mathrm{BrO}$ observed by satellites have traditionally been associated with these emissions. However, airborne measurements of $\mathrm{BrO}$ and $\mathrm{O}_{3}$ within the convective boundary layer (CBL) during the ARCTAS and ARCPAC field campaigns at times bear little relation to enhanced column BrO. We show that the locations of numerous satellite $\mathrm{BrO}$ "hotspots" during Arctic spring are consistent with observations of total column ozone and tropopause height, suggesting a stratospheric origin to these regions of elevated $\mathrm{BrO}$. Tropospheric enhancements of $\mathrm{BrO}$ large enough to affect the column abundance are also observed, with important contributions originating from above the CBL. Closure of the budget for total column $\mathrm{BrO}$, albeit with significant uncertainty, is achieved by summing observed tropospheric partial columns with calculated stratospheric partial columns provided that natural, short-lived biogenic bromocarbons supply between 5 and $10 \mathrm{ppt}$ of bromine to the Arctic lowermost stratosphere. Proper understanding of bromine and its effects on atmospheric composition requires accurate treatment of geographic variations in column $\mathrm{BrO}$ originating from both the stratosphere and troposphere. Citation: Salawitch, R. J., et al. (2010), A new interpretation of total column BrO during Arctic spring, Geophys. Res. Lett., 37, L21805, doi:10.1029/2010GL043798.

\footnotetext{
${ }^{1}$ Department of Atmospheric and Oceanic Science, University of Maryland, College Park, Maryland, USA.

${ }^{2}$ Department of Chemistry and Biochemistry, University of Maryland, College Park, Maryland, USA.

${ }^{3}$ Earth System Science Interdisciplinary Center, University of Maryland, College Park, Maryland, USA.

${ }^{4}$ Harvard-Smithsonian Center for Astrophysics, Cambridge, Massachusetts, USA.

${ }^{5}$ GEST, University of Maryland Baltimore County, Greenbelt, Maryland, USA.

${ }^{6}$ NASA Goddard Space Flight Center, Greenbelt, Maryland, USA.

${ }^{7}$ Science Systems and Applications, Inc., Lanham, Maryland, USA.

${ }^{8}$ School of Earth and Atmospheric Science, Georgia Institute of Technology, Atlanta, Georgia, USA.
}

Copyright 2010 by the American Geophysical Union. 0094-8276/10/2010GL043798

\section{Introduction}

[2] Regions of elevated $\mathrm{BrO}$ at high northerly latitudes during spring associated with the autocatalytic release of bromine from sea-salt aerosol, frost flowers, ice leads, and snow, commonly called the "bromine explosion", cause complete removal of surface ozone [e.g., Barrie et al., 1988; Platt and Hönninger, 2003]. Satellite observations of enhanced column $\mathrm{BrO}$ during spring, which we term " $\mathrm{BrO}$ hotspots" (regions where total column $\mathrm{BrO}$ is elevated by 2 to $3 \times 10^{13} \mathrm{~cm}^{-2}$ relative to the zonal mean), have long been associated with the surface release of bromine and ozone depletion events (ODEs) [e.g., Chance, 1998; Richter et al., 1998; Wagner et al., 2001].

[3] There is also widespread interest in atmospheric $\mathrm{BrO}$ due to its role as a catalyst for loss of ozone in the stratosphere [e.g., Salawitch et al., 2005] and upper troposphere [e.g., von Glasow et al., 2004]. Oxidation by reaction with atomic $\mathrm{Br}$ could be the dominant sink for elemental mercury, with important consequences for mercury deposition [e.g., Holmes et al., 2006]. Reaction with $\mathrm{BrO}$ could be a significant sink for dimethlysulfide in the marine boundary layer, reducing subsequent production of $\mathrm{SO}_{2}$ and new cloud condensation nuclei [e.g., von Glasow et al., 2004].

[4] Satellite observations provide the best constraint on the global distribution of $\mathrm{BrO}$. Measurements of the vertical column abundance of $\mathrm{BrO}\left(\mathrm{BrO}^{\mathrm{VC}}\right)$ reveal much higher amounts (i.e., factor of 2 or 3 more) than found in standard

\footnotetext{
${ }^{9}$ Complex Systems Research Center, University of New Hampshire, Durham, New Hampshire, USA.

${ }^{10}$ Department of Chemistry and Biochemistry, University of Alaska Fairbanks, Fairbanks, Alaska, USA.

${ }^{11}$ National Center for Atmospheric Research, Boulder, Colorado, USA.

${ }^{12}$ CIRES, University of Colorado at Boulder, Boulder, Colorado, USA.

${ }^{13}$ Earth System Research Laboratory, NOAA, Boulder, Colorado, USA.

${ }^{14}$ Department of Chemistry, University of California, Irvine, California, USA.

${ }^{15}$ RSMAS, University of Miami, Miami, Florida, USA.

${ }^{16}$ Belgian Institute for Space Aeronomy, Brussels, Belgium.

${ }^{17}$ NIWA Lauder, Omakau, New Zealand.

${ }^{18}$ NASA Ames Research Center, Moffett Field, California, USA.

${ }^{19}$ NASA Langley Research Center, Hampton, Virginia, USA.

${ }^{20}$ NESDIS, NOAA, Madison, Wisconsin, USA.

${ }^{21}$ School of Engineering and Applied Sciences, Harvard University, Cambridge, Massachusetts, USA.
} 
models. Considerable debate has centered on the relative role of contributions from the stratosphere and troposphere to this difference [e.g., Richter et al., 1998; Salawitch et al., 2005].

[5] Traditionally, the tropospheric BrO burden has been obtained by subtracting a background from the measured satellite signal, accounting for different air mass factors (ratio of light path through the atmosphere to a vertical path) of the stratospheric and tropospheric components [e.g., Wagner et al., 2001]. The background is commonly based on a longitudinally invariant stratosphere, although potential errors of this approach have been noted [e.g., Richter et al., 1998]. Significant effort has been devoted to measuring the near surface mixing ratio of $\mathrm{BrO}$ during Arctic spring [e.g., Platt and Hönninger, 2003, and references therein]. Prior measurements in the Arctic from aircraft [McElroy et al., 1999] and ground-based [Hönninger et al., 2004] instruments suggest the presence of significant levels of tropospheric BrO above the top of the convective boundary layer (CBL, characterized by constant potential temperature with respect to altitude), further complicating our ability to relate satellite observations of $\mathrm{BrO}^{\mathrm{VC}}$ to surface ODEs. Quantitative closure of the budget for $\mathrm{BrO}^{\mathrm{VC}}$ has heretofore not been achieved [e.g., Ridley et al., 2007].

[6] This paper is focused on quantification of contributions from the troposphere and the stratosphere to $\mathrm{BrO}^{\mathrm{VC}}$ during Arctic spring. Enhancements of BrO large enough to be recorded as a satellite "hotspot" are associated with the compression of stratospheric air to high pressure in regions of a low altitude tropopause. Consequently, the notion that the stratospheric contribution to total column $\mathrm{BrO}$ can be approximated by a constant background is flawed. Our observations demonstrate that the tropospheric burden of $\mathrm{BrO}$ can also contribute to $\mathrm{BrO}^{\mathrm{VC}}$ at a magnitude consistent with satellite "hotspots" and that a significant portion of the tropospheric signal originates from above the top of the CBL, a region not typically sampled by ground based instruments. We show that closure of the budget for $\mathrm{BrO}^{\mathrm{VC}}$ can be achieved by summing observed tropospheric partial column $\mathrm{BrO}$ with calculated stratospheric partial column $\mathrm{BrO}$, albeit with significant uncertainty in each term. This represents a significant step forward in our understanding of atmospheric BrO.

\section{Observations and Model Description}

\subsection{OMI BrO}

[7] OMI is on the NASA Aura platform in a sunsynchronous orbit with a 1:38 pm equator crossing time (ascending node). $\mathrm{BrO}^{\mathrm{VC}}$ is retrieved from reflected sunlight observed in nadir. The algorithm is based on non-linear, least-squares fitting of radiances in the 319 to $347.5 \mathrm{~nm}$ window [Chance, 1998]. $\mathrm{BrO}^{\mathrm{VC}}$ is found using wavelength dependent air mass factors, computed with a multiple scattering radiative transfer model. Contributions from the $\mathrm{O}_{2}$ dimer have been neglected, resulting in lower noise and smaller fitting uncertainties than the operational OMI BrO product. Surface albedo is based on a geographically varying, monthly mean climatology derived from OMI observations [Kleipool et al., 2008]. Typically, the fitting residual leads to $\mathrm{a} \pm 22 \%$ uncertainty $(1 \sigma)$ for $\mathrm{BrO}^{\mathrm{VC}}$.
[8] Retrievals of $\mathrm{BrO}^{\mathrm{VC}}$ from OMI compare extremely well with estimates from ground-based instruments located in Harestua, Norway $\left(60.2^{\circ} \mathrm{N}, 11^{\circ} \mathrm{E}\right)$ and Lauder, New Zealand $\left(45.0^{\circ} \mathrm{S}, 169.7^{\circ} \mathrm{E}\right)$. The ground-based and satellite measurements agree within $15 \%$, with no discernable bias. The auto-correlation of errors in the state vector elements of $\mathrm{BrO}^{\mathrm{VC}}$ and $\mathrm{O}_{3}$ column, from a simultaneous retrieval, is negligible. We therefore conclude regions of enhanced $\mathrm{BrO}^{\mathrm{VC}}$ are not an artifact caused by the treatment of $\mathrm{O}_{3}$ in the retrieval algorithm. Further details of the retrieval and these comparisons are given in the auxiliary material. ${ }^{1}$

\subsection{Aircraft BrO and Related Species}

[9] A variety of aircraft observations are used. The DC-8 and WP-3D aircraft flown during the NASA ARCTAS (Arctic Research of the Composition of the Troposphere from Aircraft and Satellites) and NOAA ARCPAC (Aerosol, Radiation, and Cloud Processes affecting Arctic Climate) campaigns carried in situ instruments that measured $\mathrm{BrO}$, $\mathrm{BrCl}$, and $\mathrm{Br}_{2}$ using chemical ionization mass spectrometry (CIMS) [Neuman et al., 2010]. The measurements of $\mathrm{BrO}$ are accurate to $\pm 40 \%+1 \mathrm{ppt}$ with a precision of $3 \mathrm{ppt}$ for a $2 \mathrm{sec}$ integration time. The DC-8 measurements are reported with $30 \mathrm{sec}$ time resolution and the WP-3D measurements are reported with $2 \mathrm{sec}$ resolution. The detection limit was typically $\sim 2 \mathrm{ppt}$ for the WP-3D instrument and between 2 to 5 ppt for the DC-8 instrument. Laboratory [Neuman et al., 2010] and field comparisons [Liao et al., 2010] indicate that $\mathrm{BrO}$ is not produced or lost on the inlets of the CIMS instruments. The presence of $\mathrm{Br}_{2}$ during daylight is thought to result from the conversion of $\mathrm{HOBr}$ to $\mathrm{Br}_{2}$ on the instrument inlet [Neuman et al., 2010]. We show time series of $\mathrm{BrO}+\mathrm{BrCl}+2 \times \mathrm{Br}_{2}$, which we term $\mathrm{BrO}_{\mathrm{x}}$. Soluble bromide was measured in a mist chamber and includes numerous condensable species. Detailed descriptions of the various instruments are given by Neuman et al. [2010].

[10] Measurements of organic bromocarbons and CFC-12 were acquired by Whole Air Sampler (WAS) instruments onboard the NASA DC- 8 aircraft during ARCTAS and TC ${ }^{4}$ (Tropical Composition, Cloud and Climate Coupling) and the NASA WB-57 aircraft during TC ${ }^{4}$. Details of the WAS instruments are given by Schauffler et al. [1999]. The WAS data are discussed primarily in the auxiliary material. In situ $\mathrm{O}_{3}$ was measured using chemiluminescence on the WP-3D and DC-8 and using a dual beam UV photometer on the WB-57.

\subsection{Ground Based BrO}

[11] Observations of tropospheric $\mathrm{BrO}$ over Barrow, Alaska $\left(71.3^{\circ} \mathrm{N}, 156.8^{\circ} \mathrm{W}\right)$ are provided by a Max-DOAS (Multi Axis Differential Optical Absorption Spectroscopy) instrument. The differential slant column density of $\mathrm{BrO}$ $\left(\mathrm{BrO}^{\mathrm{dSCD}}\right)$ is found as a function of elevation angle (EA) of the acquired spectra [Hönninger et al., 2004]. A radiative transfer program is used to model the variation of $\mathrm{BrO}^{\mathrm{dSCD}}$ with EA, for various assumptions regarding the height distribution of BrO. This technique provides a strong constraint on the distribution of $\mathrm{BrO}$ within the lowest several $\mathrm{km}$ of the troposphere.

\footnotetext{
${ }^{1}$ Auxiliary materials are available in the HTML. doi:10.1029/ 2010GL043798.
} 


\subsection{Stratospheric Model BrO}

[12] Calculation of the vertical column abundance of stratospheric $\mathrm{BrO}\left(\mathrm{BrO}^{\mathrm{STRAT}}\right)$ is central to this paper. The calculation begins with global profiles of $\mathrm{CFC}-12$ found by a GEOS-5 assimilation conducted for ARCTAS, with surface emission and stratospheric destruction of CFC-12 [Liang et al., 2008]. CFC-12 is output on a $0.5^{\circ} \times 0.67^{\circ}$ (lat/lon) grid for 72 pressure levels, from the surface to $0.01 \mathrm{hPa}$, every 6 hours. Comparison to aircraft observations (see auxiliary material) demonstrates that modeled CFC-12 is accurate to within $\pm 4 \%$ in the lower stratosphere. Values of $\mathrm{Br}_{\mathrm{y}}$ (total inorganic bromine) are found from CFC-12, using the method of Wamsley et al. [1998]. The baseline value for $\mathrm{Br}_{\mathrm{y}}$ assumes supply of stratospheric inorganic bromine $\left(\mathrm{Br}_{\mathrm{y}}\right)$ from $\mathrm{CH}_{3} \mathrm{Br}$, halons, and $\mathrm{CH}_{2} \mathrm{Br}_{2}$.

[13] We also conduct simulations of $\mathrm{BrO}$ assuming supply of an additional 5 and $10 \mathrm{ppt}$ of $\mathrm{Br}_{\mathrm{y}}$ from very short lived (VSL) bromocarbons, termed $\mathrm{Br}_{\mathrm{y}}^{\mathrm{VSL}}$. Since our baseline value of $\mathrm{Br}_{\mathrm{y}}$ includes a contribution from $\mathrm{CH}_{2} \mathrm{Br}_{2}$ by source gas injection (SGI) into the stratosphere, our definition of $\mathrm{Br}_{\mathrm{y}}^{\mathrm{VSL}}$ differs from that used by World Meteorological Organization $(W M O)$ [2007]. The relation of our definition of $\mathrm{Br}_{\mathrm{y}}^{\mathrm{VSL}}$ to $W M O$ [2007] and justification for use of 5 and $10 \mathrm{ppt}$ levels of $\mathrm{Br}_{\mathrm{y}}^{\mathrm{VSL}}$ based on the WAS measurements are discussed in the auxiliary material. Briefly, $\mathrm{CBr}_{\mathrm{y}}$ (total organic bromine) was observed to reach upwards of $30 \mathrm{ppt}$ in the tropical marine boundary layer and to exceed $25 \mathrm{ppt}$ in the region of convective outflow in the tropical upper troposphere during $\mathrm{TC}^{4}$. These observations, together with WAS measurements that show direct injection of VSL species into the Arctic lowermost stratosphere (LMS), support the plausibility that $\mathrm{Br}_{\mathrm{y}}$ in the Arctic LMS was 5 to $10 \mathrm{ppt} \mathrm{higher} \mathrm{than} \mathrm{our} \mathrm{baseline}$ value of $\mathrm{Br}_{\mathrm{y}}$.

[14] Once $\mathrm{Br}_{\mathrm{y}}$ is specified, $\mathrm{BrO}$ is found using the $\mathrm{BrO} /$ $\mathrm{Br}_{\mathrm{y}}$ ratio from a run of WACCM (Whole Atmosphere Community Climate Model) [Garcia et al., 2007] conducted for the START08 (Stratosphere-Troposphere Analyses of Regional Transport 2008) campaign (April to June 2008). WACCM output, provided every $3 \mathrm{hrs}$ on a $1.9^{\circ} \times 2.5^{\circ}$ (lat/lon) grid for 89 pressure levels ranging from 1000 to $4.5 \times$ $10^{-6} \mathrm{hPa}$, is interpolated to the finer GEOS-5 grid for the time of OMI overpass. A single run of WACCM that considered supply of $\mathrm{Br}_{\mathrm{y}}$ from only $\mathrm{CH}_{3} \mathrm{Br}$ and halons is used; we adjust $\mathrm{Br}_{\mathrm{y}}$ outside of WACCM and rely on WACCM for the $\mathrm{BrO} / \mathrm{Br}_{\mathrm{y}}$ ratio (which is insensitive to $\mathrm{Br}_{\mathrm{y}}$ for the range of variations used in this study). We use this procedure because $\mathrm{BrO} / \mathrm{Br}_{\mathrm{y}}$ is sensitive to $\mathrm{O}_{3}$ and $\mathrm{NO}_{2}$ [e.g., Theys et al., 2009] and the START08 WACCM run provides an estimate of $\mathrm{O}_{3}$ and $\mathrm{NO}_{2}$ for conditions specific to spring 2008. WACCM calculations of $\mathrm{O}_{3}, \mathrm{NO}_{\mathrm{x}}$ and $\mathrm{NO}$ compare extremely well to observations of these species obtained during ARCTAS and START08. A description of WACCM and demonstration of its performance, including excellent evaluation of the $\mathrm{BrO} /$ $\mathrm{Br}_{\mathrm{y}}$ ratio, is given by Chipperfield and Kinnison [2010]. $\mathrm{BrO}^{\text {STRAT }}$ is found by integrating model profiles of $\mathrm{BrO}$ from the tropopause (WMO definition of thermal tropopause) to the top of the model atmosphere, for the time of OMI overpass.

[15] A photochemical steady state model is used to assess the uncertainty in $\mathrm{BrO}^{\text {STRAT }}$. This model has been constrained to profiles of $\mathrm{O}_{3}, \mathrm{NO}_{\mathrm{y}}, \mathrm{Br}_{\mathrm{y}}$, etc. from WACCM as described by Chipperfield and Kinnison [2010]. The rate constant of each reaction that affects $\mathrm{BrO} / \mathrm{Br}_{\mathrm{y}}$ is varied using uncertainties of Sander et al. [2006]. The total uncertainty in $\mathrm{BrO}^{\text {STRAT }}$ is found from a root-sum-squares combination of the individual chemical kinetics terms (including $\mathrm{J}$ values) and propagation, through the model, of the impact of a $4 \%$ error in the specification of CFC-12 in the lowermost stratosphere. The reaction of $\mathrm{BrO}+\mathrm{NO}_{2}$ forming $\mathrm{BrNO}_{3}$, which is uncertain by a factor of 2 at $220 \mathrm{~K}$, contributes most to the overall uncertainty [e.g., Hendrick et al., 2008]. The $1 \sigma$ uncertainty in $\mathrm{BrO}^{\mathrm{STRAT}}$ for the $\mathrm{Br}_{\mathrm{y}}^{\mathrm{VSL}}=10 \mathrm{ppt}$ simulation is $\pm 30 \%$ (globally) and $\pm 45 \%$ (region of low altitude tropopause), with larger uncertainties near the low altitude tropopause due to increased importance of $\mathrm{BrO}+$ $\mathrm{NO}_{2}$.

\section{Results}

\subsection{Comparison of Airborne and Satellite BrO}

[16] Observations of enhanced $\mathrm{BrO}_{x}$ and soluble bromide as well as depleted ozone obtained by the DC- 8 aircraft during ARCTAS often bear little relation to the location of OMI BrO ${ }^{\text {VC }}$ "hotspots". Measurements obtained on 5 and 8 April 2008 are shown in Figure 1. Several extended low altitude legs (aircraft below $0.3 \mathrm{~km}$ ) were targeted for regions of elevated $\mathrm{BrO}$, based on analysis of OMI observations from the prior day. These flight portions are denoted by purple line segments for the flight track and altitude traces. The instruments recorded little perturbation to ambient $\mathrm{O}_{3}, \mathrm{BrO}_{x}$, and soluble bromide in the regions where $\mathrm{OMI} \mathrm{BrO}^{\mathrm{VC}}$ was highly enhanced. Furthermore, a major ODE co-located with highly enhanced $\mathrm{BrO}_{x}$ and soluble bromide was observed on 8 April 2008 near $83^{\circ} \mathrm{N}, 65^{\circ} \mathrm{W}$, far from the region of elevated $\mathrm{BrO}^{\mathrm{VC}}$ (pink circle). Interpolation of $\mathrm{OMI} \mathrm{BrO}{ }^{\mathrm{VC}}$ along the $\mathrm{DC}-8$ flight track (bottom panel) exhibits no meaningful correlation with any of the DC-8 measurements. This set of observations, representative of the majority of data obtained during ARCTAS and ARCPAC, challenges pre-conceived notions of the relation between ODEs and satellite measurements of enhanced column BrO.

\subsection{Importance of the Stratosphere}

[17] Figure 2 shows total column $\mathrm{O}_{3}$, tropopause pressure, $\mathrm{BrO}^{\mathrm{VC}}$, and modeled $\mathrm{BrO}^{\mathrm{STRAT}}$ for 5 to 9 April 2008 . Column $\mathrm{O}_{3}$ is from the standard OMI product, available at http:// disc.sci.gsfc.nasa.gov/Aura/data-holdings/OMI/omto3d_v003. shtml. The region of elevated $\mathrm{BrO}$ over Hudson Bay is coincident with a low tropopause $(\sim 5 \mathrm{~km}$ altitude or $\sim 450 \mathrm{hPa}$ pressure) and high total column $\mathrm{O}_{3}(\sim 450 \mathrm{DU})$. These features progress in a similar counter-clockwise fashion, suggesting the enhancements in $\mathrm{BrO}^{\mathrm{VC}}$ originate from above the tropopause. Enhanced $\mathrm{BrO}^{\mathrm{STRAT}}$ is associated with a synoptic weather pattern characterized by a low altitude tropopause and high column $\mathrm{O}_{3}$. The preponderance of prior observations of elevated column $\mathrm{BrO}$ over Hudson Bay during spring may be related to a weather pattern known as the Hudson Bay low that is responsible for the depressed tropopause [Liu and Moore, 2004].

[18] An important feature of the satellite data is the compact, monotonic relation between $\mathrm{BrO}^{\mathrm{VC}}$ and column $\mathrm{O}_{3}$ for data acquired with solar zenith angle (SZA) $\leq 80^{\circ}$ (Figure 3). The monotonic nature of this relation (i.e., $\mathrm{BrO}^{\mathrm{VC}}$ rises as column $\mathrm{O}_{3}$ increases) provides strong 
5 April 2008 $\mathrm{OMl}$ BrOve
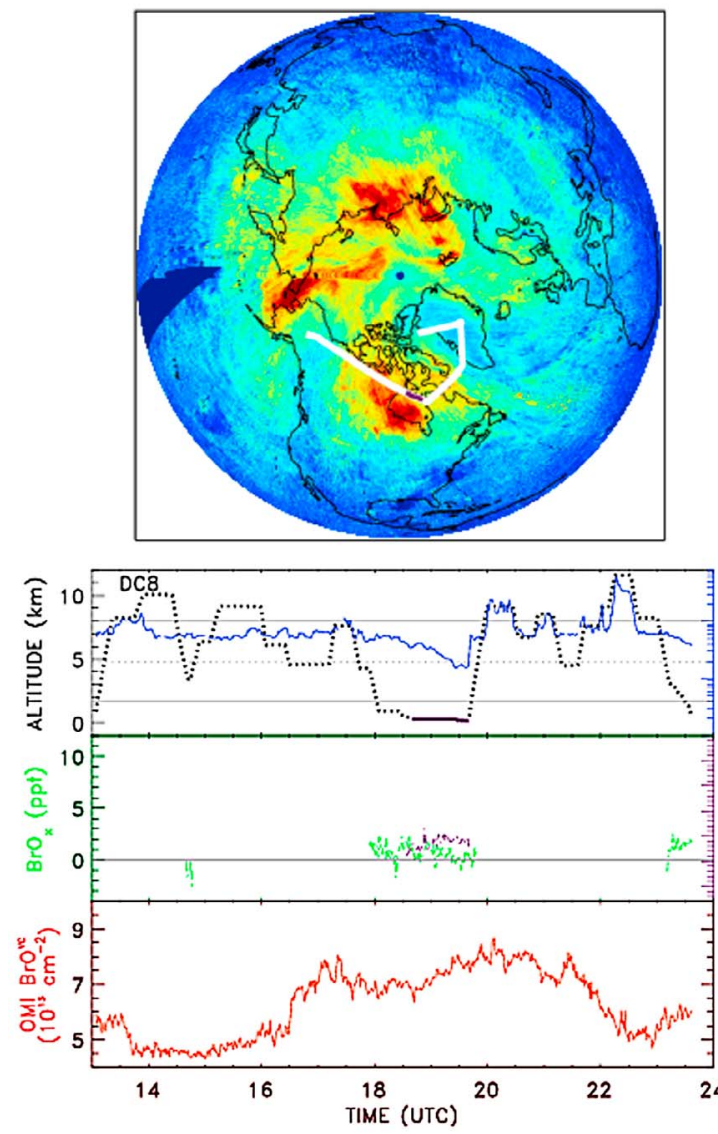
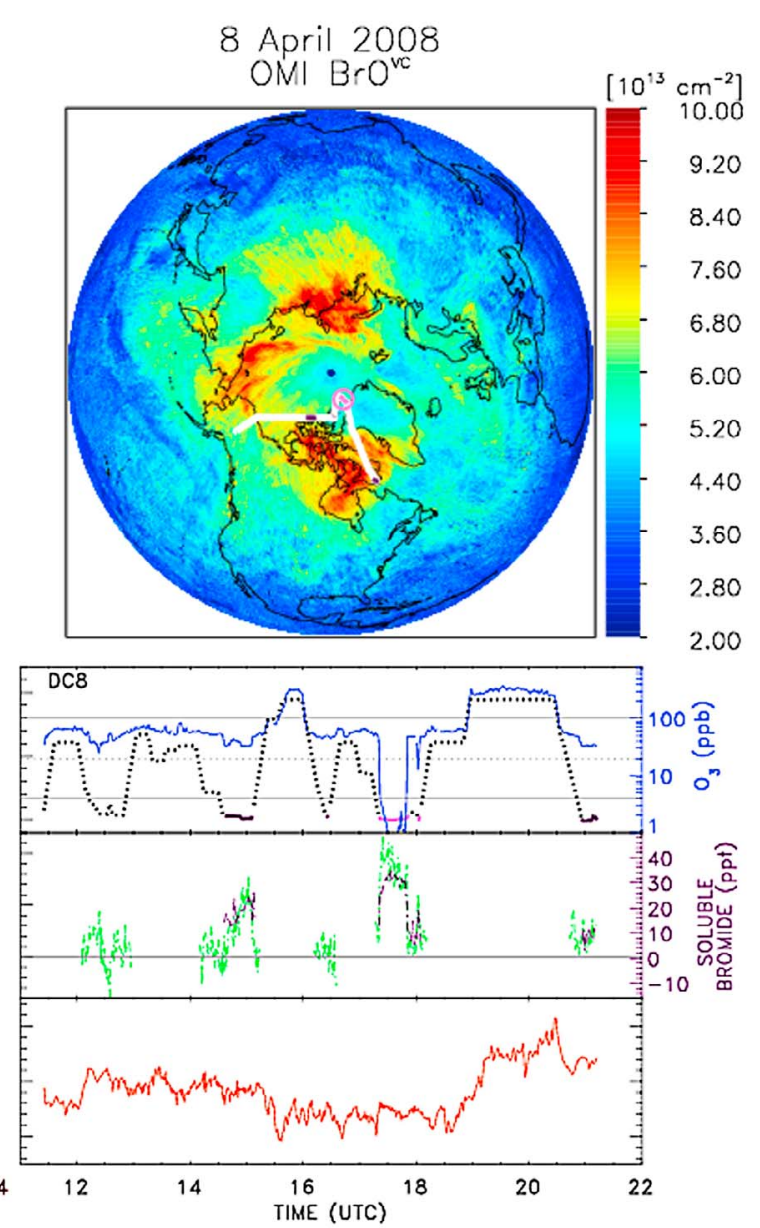

Figure 1. (top) $\mathrm{OMI} \mathrm{BrO}^{\mathrm{VC}}$ on 5 and 8 April 2008; (middle) time series of $\mathrm{O}_{3}$ (blue), $\mathrm{BrO}_{x}$ (green), and soluble bromide (purple) measured by instruments onboard the NASA DC- 8 on these dates; and, (bottom) an interpolation of OMI $\mathrm{BrO}^{\mathrm{VC}}$ along the DC-8 flight track. The 5 April flight landed in Fairbanks and the 8 April fight originated from Fairbanks. BrO was below the detection limit of $\sim 5 \mathrm{ppt}$ (later flights had lower detections limits) and $\mathrm{BrO}_{x}$ for these dates reflects the presence of other gas phase bromine-bearing species. The DC- 8 flight track is shown by white lines on the OMI images and DC- 8 altitude is shown by the black dotted line; purple portions denote altitude $<0.3 \mathrm{~km}$ and pink indicates altitude $<0.3 \mathrm{~km}$ in the presence of a major ODE $\left(\mathrm{O}_{3}<4 \mathrm{ppb}\right)$. Location of a major ODE on 8 April is denoted by the pink circle on the OMI image.

empirical support for the notion that a significant portion of the enhancement in $\mathrm{BrO}^{\mathrm{VC}}$ originates from above the tropopause. Figure 3 also shows the calculated relation between $\mathrm{BrO}^{\text {STRAT }}$ and column $\mathrm{O}_{3}$; thin error bars represent $1 \sigma$ overall uncertainty. Between 5 and 10 ppt of $\mathrm{Br}_{\mathrm{y}}$, in excess to that of the baseline, must be present in the Arctic lowermost stratosphere to obtain a theoretical relation with a slope $\left[\mathrm{dBrO}^{\mathrm{VC}} / \mathrm{d}\left(\mathrm{O}_{3}\right.\right.$ column $\left.)\right]$ similar to that observed. The relation between $\mathrm{BrO}^{\mathrm{VC}}$ and column $\mathrm{O}_{3}$ breaks down for $\mathrm{SZA} \geq \sim 85^{\circ}$ (not shown) as $\mathrm{BrO}$ goes into its nighttime reservoirs, further supporting our confidence that the relation between enhanced $\mathrm{BrO}$ and elevated $\mathrm{O}_{3}$ is not a retrieval artifact. Departures from linearity of the observed relation, compared to the near linear theoretical expectation, could be due to the influence of the troposphere (i.e., high column $\mathrm{O}_{3}$ tends to occur at Arctic latitudes, where the tropospheric influence is likely largest) or could represent a shortcoming of the theoretical relations.

[19] Modeled $\mathrm{BrO}^{\mathrm{STRAT}}$ for $\mathrm{Br}_{\mathrm{y}}^{\mathrm{VSL}}=10 \mathrm{ppt}$ resembles $\mathrm{OMI} \mathrm{BrO}^{\mathrm{VC}}$ (Figures 2 and 3 ). The $\mathrm{Br}_{\mathrm{y}}^{\mathrm{VSL}}=5$ ppt simulation of $\mathrm{BrO}^{\text {STRAT }}$ shows similar features, whereas $\mathrm{BrO}^{\mathrm{STRAT}}$ found for $\mathrm{Br}_{\mathrm{y}}^{\mathrm{VSL}}=0$ (standard for many ozone loss simulations) is quite different than the data. The last row of Figure 2 shows measured $\mathrm{BrO}^{\mathrm{VC}}$ on 6 April 2008 and modeled $\mathrm{BrO}^{\mathrm{STRAT}}$ for $\mathrm{Br}_{\mathrm{y}}^{\mathrm{VSL}}=5$ and $10 \mathrm{ppt}$, with each quantity perturbed by its $1 \sigma$ uncertainty. This row reinforces the notion that OMI $\mathrm{BrO}^{\mathrm{VC}}$ is consistent with $\mathrm{Br}_{\mathrm{y}}^{\mathrm{VSL}}$ between 5 and 10 ppt.

[20] Modeled $\mathrm{BrO}^{\text {STRAT }}$ assumes no contribution from below the tropopause. The high $\mathrm{BrO}^{\mathrm{VC}}$ observed to persist over Hudson Bay on 8 and 9 April 2008 could be due to irreversible mixing of stratospheric air into the UT after passage of the frontal system. Irreversible, cross tropopause exchange of air from the stratosphere to the troposphere (STE) often occurs on the western flank of Arctic low pressure systems [Gettelman and Sobel, 2000]. There is strong similarity between the crescent shaped region of elevated $\mathrm{BrO}^{\mathrm{VC}}$ seen by many satellite instruments and the areas where STE is thought to occur [Wernli and Sprenger, 2007]. The presence of significant levels of $\mathrm{BrO}$ near the surface will also affect the comparison of modeled and measured $\mathrm{BrO}^{\mathrm{VC}}$. Quantification of the budget for $\mathrm{BrO}^{\mathrm{VC}}$ 

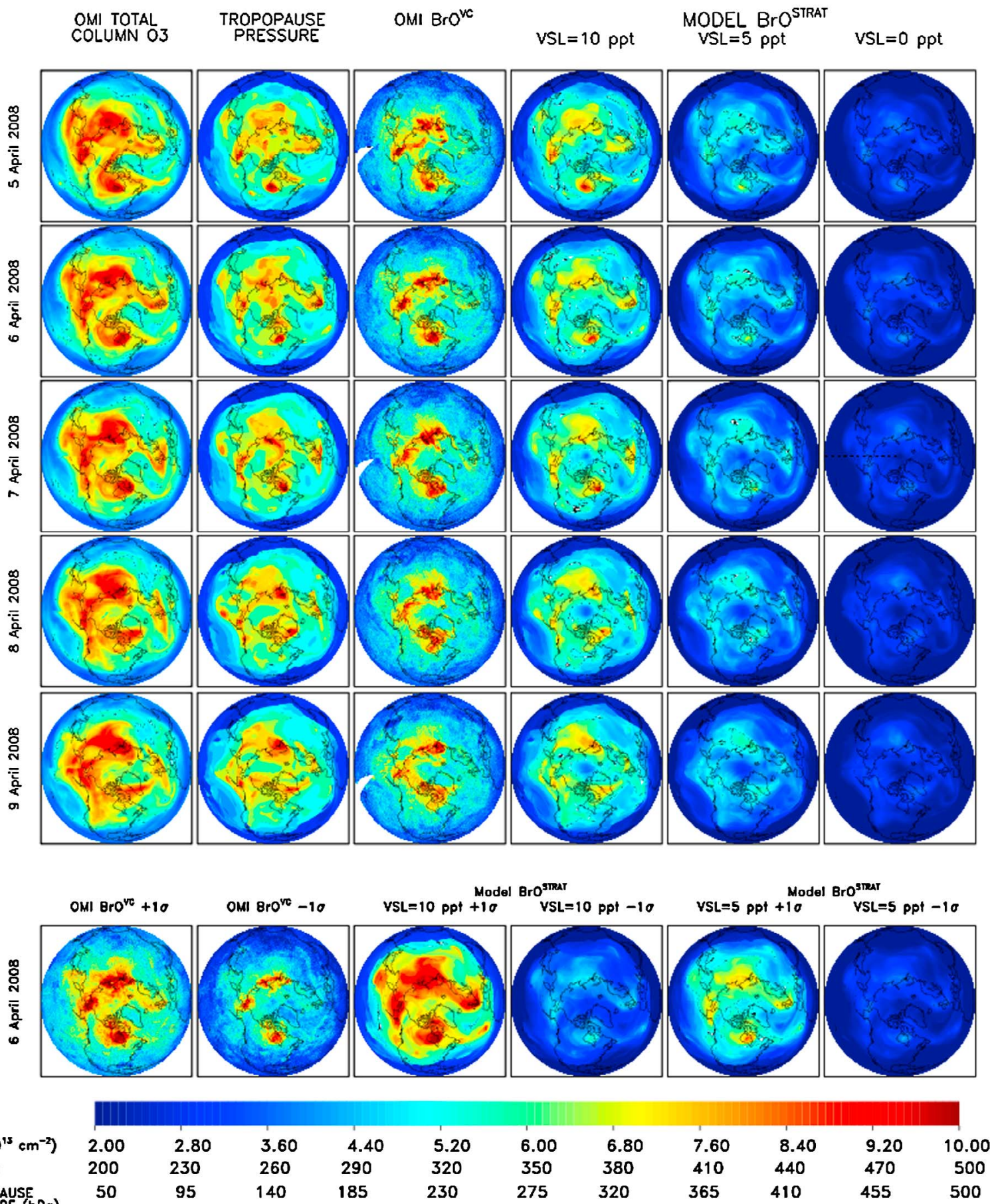

Figure 2. Measured column $\mathrm{O}_{3}(\mathrm{OMI})$, calculated tropopause pressure (GEOS-5), measured $\mathrm{BrO}^{\mathrm{VC}}(\mathrm{OMI})$, and calculated $\mathrm{BrO}^{\mathrm{STRAT}}$ for the $\mathrm{Br}_{\mathrm{y}}^{\mathrm{VSL}}=10,5$, and 0 ppt cases, for 5 to 9 April 2008 . The bottom row shows $\mathrm{BrO}^{\mathrm{VC}}$ and $\mathrm{BrO}^{\mathrm{STRAT}}$ for the $\mathrm{Br}_{\mathrm{y}}^{\mathrm{VSL}}=10$ and $5 \mathrm{ppt}$ cases, for 6 April 2008 , with each quantity perturbed by its $1 \sigma$ uncertainty. Data and model have been filtered for $\mathrm{SZA} \leq 80^{\circ}$.

requires consideration of contributions from the troposphere as well as the stratosphere.

\subsection{Importance of the Troposphere}

[21] Airborne observations of $\mathrm{BrO}$ show that the tropospheric burden also makes significant contributions to total column BrO. We have computed vertical column tropospheric $\mathrm{BrO}\left(\mathrm{BrO}^{\mathrm{TROP}}\right)$ for 29 profiles of $\mathrm{BrO}$ measured during ARCTAS and ARCPAC. Further discussion of measurement uncertainty, which approaches the value of $\mathrm{BrO}^{\mathrm{TROP}}$, is given in the auxiliary material. Many profiles occurred near Barrow, Alaska, where elevated surface BrO 


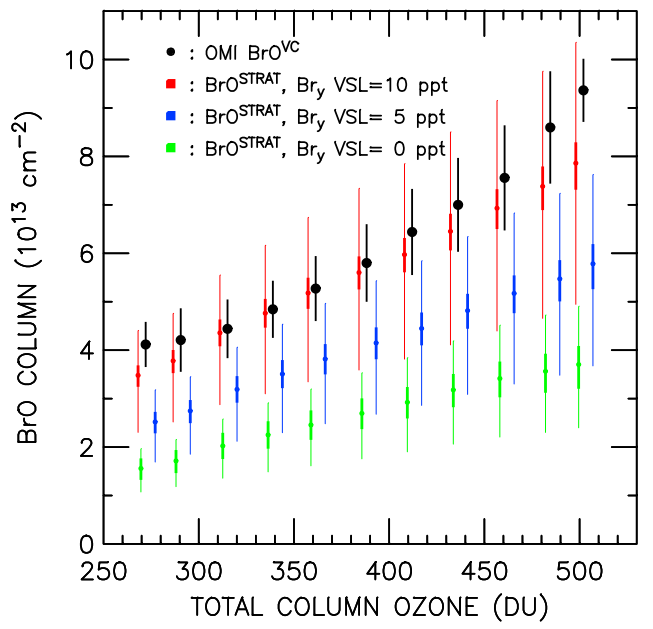

Figure 3. $\mathrm{BrO}^{\mathrm{VC}}$ versus total column $\mathrm{O}_{3}$ from $\mathrm{OMI}$ for data acquired for 5 to 9 April 2008, the five days shown in Figure 2 (black points). The error bars on $\mathrm{BrO}^{\mathrm{VC}}$ represent the standard deviation, about the mean, of the values in the respective total column $\mathrm{O}_{3}$ bins (250 to $525 \mathrm{DU}$, every $25 \mathrm{DU})$. The green, blue, and red points represent calculated $\mathrm{BrO}^{\mathrm{STRAT}}$ for $\mathrm{Br}_{\mathrm{y}}^{\mathrm{VSL}}$ of 0,5 , and $10 \mathrm{ppt}$, respectively. The thick error bar for $\mathrm{BrO}^{\text {STRAT }}$ represents the uncertainty in model BrO due to errors in GEOS-5 CFC-12; the thin error bar represents the total $1 \sigma$ uncertainty in $\mathrm{BrO}^{\mathrm{STRAT}}$, which is dominated by the factor of 2 uncertainty in $\mathrm{k}_{\mathrm{BrO}+\mathrm{NO} 2+\mathrm{M}}$. The $\mathrm{BrO}^{\text {STRAT }}$ points have been displaced slightly, with respect to the mean $\mathrm{O}_{3}$ of each bin, for clarity of error bars.

and ODEs are often observed. Most profiles were obtained in clear sky. Profiles acquired on 16 April 2008 by the DC-8 are shown in Figure 4. The flight track is superimposed on OMI $\mathrm{BrO}^{\mathrm{VC}}$ (Figure 4a) and modeled $\mathrm{BrO}^{\mathrm{STRAT}}$ (Figure $4 \mathrm{~b}$ ). Elevated OMI $\mathrm{BrO}^{\mathrm{VC}}$ is remarkably well aligned with the underlying sea, suggesting an association with surface release of bromine. The largest value of $\mathrm{BrO}^{\mathrm{TROP}}$ observed this day, $3.9 \times 10^{13} \mathrm{~cm}^{-2}$, is co-located with a local maximum in OMI $\mathrm{BrO}^{\mathrm{VC}}$.

[22] The most significant contribution to $\mathrm{BrO}^{\mathrm{TROP}}$ on 16 April 2008 was from altitudes well above the CBL. For the highlighted profile, the CBL had a ceiling of $\sim 0.2 \mathrm{~km}$ (Figure 4e). The WP-3D aircraft sampled extensively above and below this altitude on 16 April and other days, at times descending to $60 \mathrm{~m}$ above the surface [Neuman et al., 2010]. The importance of $\mathrm{BrO}$ above the $\mathrm{CBL}$ to $\mathrm{BrO}^{\mathrm{TROP}}$ is common to all profiles acquired during ARCTAS and ARCPAC (auxiliary material). ARCTAS and ARCPAC aircraft measurements reveal lower abundances of $\mathrm{BrO}$ in the CBL than reported in past ground-based studies [e.g., Platt and Hönninger, 2003]. The aircraft flights, by design, often sampled $\mathrm{O}_{3}$ depleted air within the CBL. Inorganic bromine shifts from $\mathrm{BrO}$ into other inorganic species as ambient $\mathrm{O}_{3}$ falls below $\sim 4 \mathrm{ppb}$, which was often the case for CBL air sampled during ARCTAS and ARCPAC [Neuman et al., 2010], perhaps accounting for the tendency for our measurements of $\mathrm{BrO}$ to be lower than prior observations in the CBL.

[23] Figure 5 shows $\mathrm{BrO}^{\mathrm{dSCD}}$ vs EA for Max-DOAS data acquired on 20 April 2008. Best agreement between mod- eled and measured $\mathrm{BrO}^{\mathrm{dSCD}}$ is found assuming a constant concentration of $\mathrm{BrO}$ within the lowest $1 \mathrm{~km}$ of the atmosphere, with a column of $2.3 \times 10^{13} \mathrm{~cm}^{-2}$. An ozonesonde showed a classic CBL extending to $0.3 \mathrm{~km}$, with $\mathrm{O}_{3}$ present uniformly at $\sim 10 \mathrm{ppb}$. A model placing all of the $\mathrm{BrO}$ within the $\mathrm{CBL}$ overestimates observed $\mathrm{BrO}^{\mathrm{dSCD}}$ at low EA and underestimates $\mathrm{BrO}^{\mathrm{dSCD}}$ at high EA, suggesting $\mathrm{BrO}$ had vented above the CBL. A significant amount of $\mathrm{BrO}$ was also present within the CBL, as demonstrated by the inability to properly simulate $\mathrm{BrO}^{\mathrm{dSCD}}$ by placing all of the $\mathrm{BrO}$ between 0.3 and $1 \mathrm{~km}$. Max-DOAS observations conducted during clear sky conditions throughout March and April 2008 (not shown) reveal contributions to $\mathrm{BrO}^{\mathrm{VC}}$ of 0 to $3 \times 10^{13} \mathrm{~cm}^{-2}$, with much of the day-to-day variability related to the direction of prevailing surface winds (higher $\mathrm{BrO}^{\mathrm{VC}}$ observed when air parcels originate from the nearby sea) (D. Donohoue et al., manuscript in preparation, 2010).

[24] The Max-DOAS and aircraft observations of tropospheric $\mathrm{BrO}$ are consistent in that they both show significant contributions to $\mathrm{BrO}^{\mathrm{TROP}}$ from above the CBL. The prevalence of elevated $\mathrm{BrO}$ above the CBL may be due to vigorous convection over ice leads driven by warm exposed water, with $\mathrm{BrO}$ then dispersed horizontally by prevailing winds. This would be consistent with distribution of $\mathrm{BrO}$ throughout the polar boundary layer, a region in which surface emissions can be vertically mixed even if the atmosphere appears to be stable with respect to local convection [e.g., Simpson et al., 2007]. Attempts to relate satellite $\mathrm{BrO}^{\mathrm{VC}}$ to ODEs and surface BrO, common in the literature, are complicated by the finding that $\mathrm{BrO}^{\mathrm{TROP}}$ appears to be dominated by contributions from above the CBL.

\subsection{Budget of Column BrO}

[25] We examine here the budget for $\mathrm{BrO}^{\mathrm{VC}}$ using the stratospheric model and tropospheric aircraft profiles. Figures $4 \mathrm{f}$ and $4 \mathrm{~g}$ show regression plots of $\mathrm{BrO}^{\mathrm{MODEL}}$ versus OMI $\mathrm{BrO}^{\mathrm{VC}}$, where $\mathrm{BrO}^{\mathrm{MODEL}}$ is set equal to $\mathrm{BrO}^{\text {STRAT }}$ (Figure 4f) or $\mathrm{BrO}^{\mathrm{STRAT}}+\mathrm{BrO}^{\mathrm{TROP}}$ (Figure $4 \mathrm{~g}$ ). Data are shown for all locations where $\mathrm{BrO}^{\mathrm{TROP}}$ can be estimated from the two aircraft: 29 profiles encompassing observations acquired on 8 days. Neglecting the tropospheric contribution to column $\mathrm{BrO}$, all modeled $\mathrm{BrO}$ columns show slopes below the 1:1 line, although the model for the largest VSL bromine contribution lies close to the line (Figure 4f).

[26] Accounting for contributions from both the troposphere and stratosphere, budget closure is achieved if $\mathrm{Br}_{\mathrm{y}}^{\mathrm{VSL}}$ lies between 5 and $10 \mathrm{ppt}$ (Figure 4g). Closure of the budget is supported quantitatively by the ratio $\mathrm{BrO}^{\mathrm{MODEL}} / \mathrm{OMI}$ $\mathrm{BrO}^{\mathrm{VC}}$ encompassing unity, within the standard deviation of the mean, for these two simulations. Strictly speaking, budget closure is achieved for values of $\mathrm{Br}_{\mathrm{y}}^{\mathrm{VSL}}$ ranging from $\sim 1.4$ to $13.2 \mathrm{ppt}$ (auxiliary material). Considerable uncertainty exists, leading to a wide range of $\mathrm{Br}_{\mathrm{v}}^{\mathrm{VSL}}$ that could be consistent with $\mathrm{OMI} \mathrm{BrO}^{\mathrm{VC}}$, because $\mathrm{BrO}^{\mathrm{VC}}$ is uncertain at $\pm 22 \%, \mathrm{BrO}^{\mathrm{STRAT}}$ is uncertain at $\pm 45 \%$ due to chemical kinetics, and $\mathrm{BrO}^{\mathrm{TROP}}$ is uncertain at an amount approaching the measured abundance (all $1 \sigma$ ). The effects of clouds, which potentially shield a portion of the tropospheric column from view of OMI, have not been considered. Nonetheless, Figure $4 \mathrm{~g}$ demonstrates a plausible means to achieve budget 

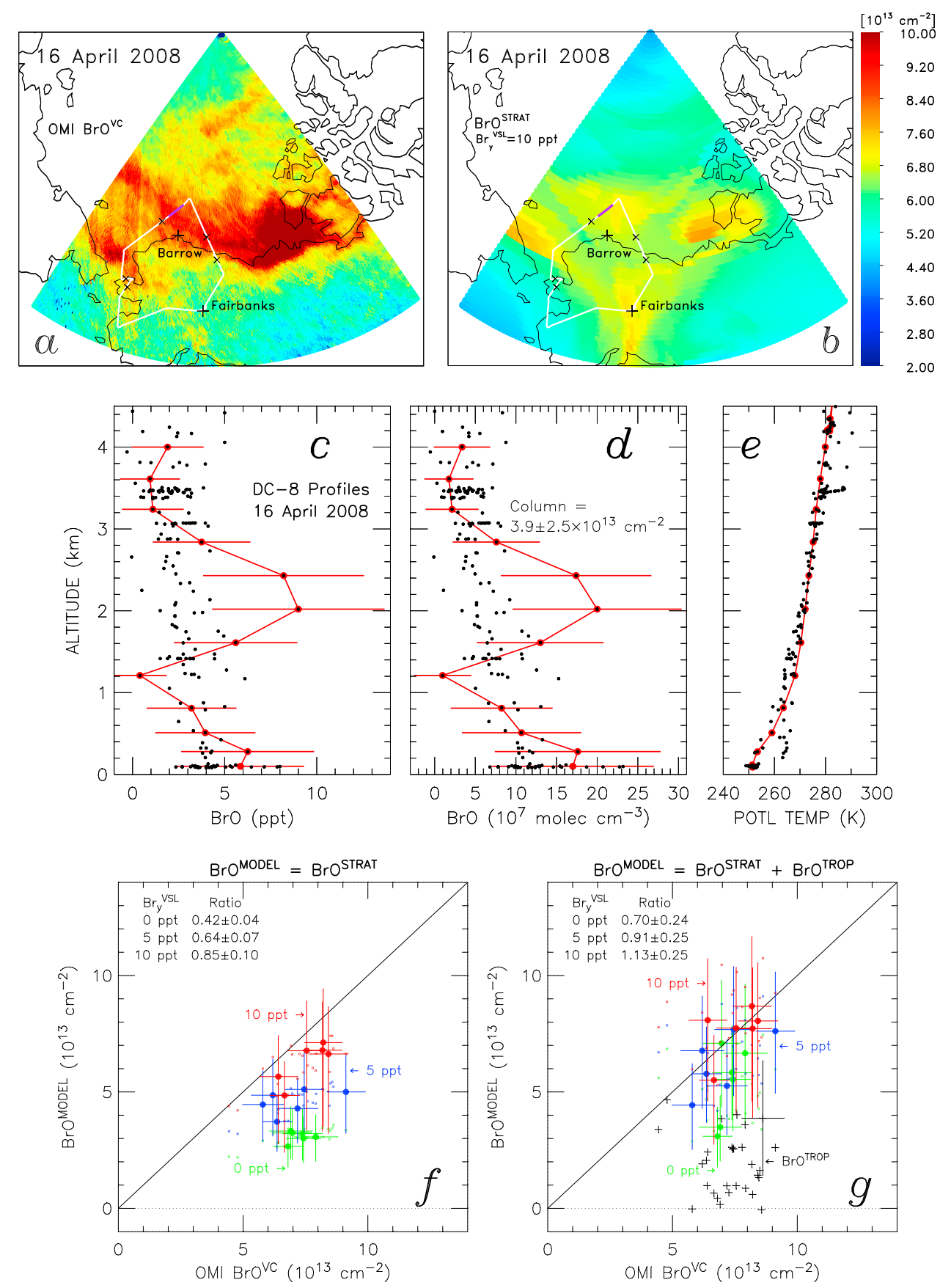

Figure 4. (a and b) Flight track of the DC-8 on 16 April 2008 (white line) superimposed on OMI measurements of $\mathrm{BrO}^{\mathrm{VC}}$ and calculated $\mathrm{BrO}^{\mathrm{STRAT}}\left(\mathrm{Br}_{\mathrm{y}}^{\mathrm{VSL}}=10 \mathrm{ppt}\right)$, respectively. (c-e) Profiles of $\mathrm{BrO}$ volume mixing ratio, $\mathrm{BrO}$ concentration, and potential temperature $(\theta)$ on 16 April 2008 (black dots); profile shown in red, with $\mathrm{BrO}^{\mathrm{TROP}}=3.9 \pm 2.5 \times 10^{13} \mathrm{~cm}^{-2}$, was measured at the segment marked in purple in Figures $4 \mathrm{a}$ and $4 \mathrm{~b} ; \times$ denotes location of other profiles. All data were acquired for $\mathrm{O}_{3}<120 \mathrm{ppb}$, assuring the sampling of tropospheric air. (f and g) Scatter plot of BrO ${ }^{\mathrm{MODEL}}$ versus OMI BrO ${ }^{\mathrm{VC}}$ for locations of the DC-8 and WP-3D measurements of $\mathrm{BrO}^{\mathrm{TROP}}$, where $\mathrm{BrO}^{\mathrm{MODEL}}=\mathrm{BrO}^{\mathrm{STRAT}}$ (Figure $4 \mathrm{f}$ ) and $\mathrm{BrO}^{\mathrm{MODEL}}=$ $\mathrm{BrO}^{\mathrm{STRAT}}+\mathrm{BrO}^{\mathrm{TROP}}$ (Figure $4 \mathrm{~g}$ ), for values of $\mathrm{BrO}^{\mathrm{STRAT}}$ from the $\mathrm{Br}_{\mathrm{y}}^{\mathrm{VSL}}=0,5$, and 10 ppt simulations. Determinations of $\mathrm{BrO}^{\mathrm{TROP}}(+)$ are shown in Figure $4 \mathrm{~g}$. Error bars for $\mathrm{OMI} \mathrm{BrO}^{\mathrm{VC}}$ represent $1 \sigma$ uncertainty due to residuals in the spectral fit. Error bars for $\mathrm{BrO}^{\mathrm{MODEL}}$ represent $1 \sigma$ uncertainty in $\mathrm{BrO}^{\mathrm{STRAT}}$ (Figure $4 \mathrm{f}$ ) and RSS combination of $1 \sigma$ uncertainty in $\mathrm{BrO}^{\mathrm{STRAT}}$ and $\mathrm{BrO}^{\mathrm{TROP}}$ (Figure $4 \mathrm{~g}$ ). For clarity, error bars are shown for every 5 th data point and just one measurement of $\mathrm{BrO}^{\mathrm{TROP}}$. Values of the ratio $\mathrm{BrO}^{\mathrm{MODEL}} / \mathrm{OMI} \mathrm{BrO}^{\mathrm{VC}}$ are indicated on Figures $4 \mathrm{f}$ and $4 \mathrm{~g}$. 
20 April 2008, Barrow, Alaska
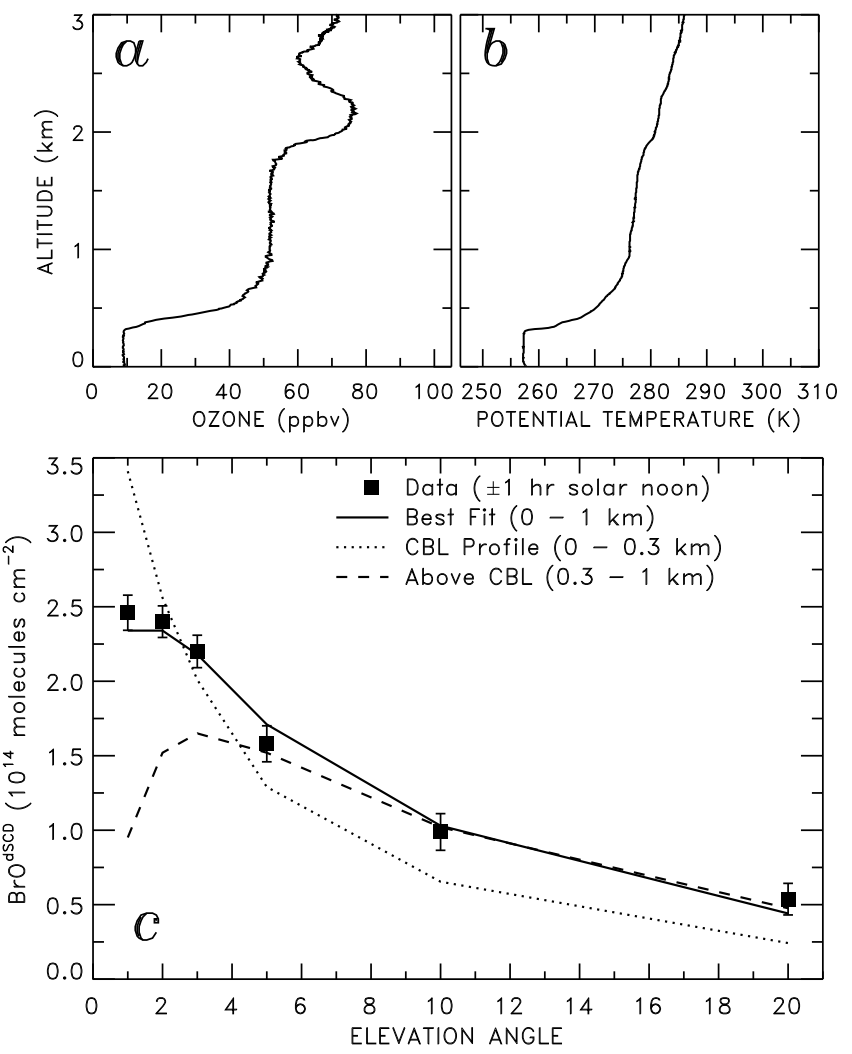

Figure 5. Measurements at Barrow, Alaska on 20 April 2008. ( $a$ and $b$ ) Profiles of $\theta$ and $\mathrm{O}_{3}$ measured by an ozonesonde. (c) Differential slant column density of $\mathrm{BrO}$ $\left(\mathrm{BrO}^{\mathrm{dSCD}}\right)$ versus Elevation Angle. Black squares are average $\mathrm{BrO}^{\mathrm{dSCD}}$ within 1 hour of local solar noon. Lines show modeled $\mathrm{BrO}^{\mathrm{dSCD}}$ for three $\mathrm{BrO}$ profiles, all with uniform concentration with respect to altitude between: the surface and $1 \mathrm{~km}$ (solid); the surface and $0.3 \mathrm{~km}$ (dotted); 0.3 to $1 \mathrm{~km}$ (dashed); $\mathrm{BrO}$ concentration is otherwise zero. The solid and dashed profiles have a BrO column of $2.3 \times 10^{13} \mathrm{~cm}^{-2}$; the dotted profile has a column of $1.3 \times 10^{13} \mathrm{~cm}^{-2}$.

closure for $\mathrm{BrO}^{\mathrm{VC}}$ that emphasizes the importance of both the troposphere and supply of stratospheric bromine from VSL sources.

\section{Concluding Remarks}

[27] Our analysis indicates significant contributions to the geographic variation in column $\mathrm{BrO}$ originate from both the stratosphere and troposphere, including regions of the troposphere above the convective boundary layer. Numerous OMI BrO "hotspots" exhibit spatial patterns similar to column $\mathrm{O}_{3}$, tropopause pressure, and modeled stratospheric $\mathrm{BrO}$, provided that VSL bromocarbons make a considerable contribution, 5 to $10 \mathrm{ppt}$, to stratospheric $\mathrm{Br}_{\mathrm{y}}$. Future attempts to relate satellite measurement of column $\mathrm{BrO}$ to surface events should account for the substantial contributions to geographic variability in $\mathrm{BrO}^{\mathrm{VC}}$ that can originate from the stratosphere. Theys et al. [2009] have developed a stratospheric $\mathrm{BrO}$ climatology, using model estimates of $\mathrm{Br}_{\mathrm{y}}$ and satellite observations of $\mathrm{O}_{3}$ and $\mathrm{NO}_{2}$, that could be applicable.
[28] Total column $\mathrm{O}_{3}$ tends to exhibit highest values during Arctic spring, often in the vicinity of Hudson Bay. Based on our examination of OMI measurements of total column $\mathrm{BrO}$ and $\mathrm{O}_{3}$ over Hudson Bay for the entirety of March and April 2008, it is likely that column BrO in this region is responding, at times, to tropospheric perturbations originating from surface release. Nonetheless, the community has likely been overestimating the extent of elevated tropospheric $\mathrm{BrO}$ at Hudson Bay, and perhaps throughout the Arctic, by associating all satellite $\mathrm{BrO}$ hotspots with high-latitude surface emission of bromine.

[29] There has been a prior attempt to relate changes in the tropospheric burden of Arctic BrO to global warming [Hollwedel et al., 2004]. Their findings may have to be reconsidered because a longitudinally invariant stratosphere was used for their estimate of tropospheric BrO. Biogenic processes in the tropical oceans [e.g., von Glasow et al., 2004] are the source of the $\mathrm{BrO}$ that ultimately drives some of the satellite hotspots seen at high-latitude during spring. The production of bromocarbons in the tropical oceans and transport of these species to the stratosphere responds to a number of forcings, such as oceanic upwelling and atmospheric convection [Salawitch, 2006, and references therein]. It is important to properly quantify the tropospheric and stratospheric contributions to column $\mathrm{BrO}$ to accurately assess the impact of bromine on ozone and to progress towards the eventual quantification of any link between climate change and atmospheric bromine.

[30] Acknowledgments. Research of many of the investigators has been supported by the ARCTAS, ACMAP, Aura, MAP, and Tropospheric Chemistry programs of the National Aeronautics and Space Administration, the ARCPAC program of the National Oceanic and Atmospheric Administration, and the START08 program of the National Science Foundation. The ground-based $\mathrm{BrO}$ activities at the Belgian Institute for Space Aeronomy (BIRA-IASB) are funded by the PRODEX contract SECPEA and the EC projects GEOmon (FP6-2005-Global-4-036677) and SHIVA (226224FP7-ENV-2008-1); BIRA-IASB thanks M. P. Chipperfield for providing SLIMCAT output used in the retrieval. We thank the pilots, flight crews, and OMI scientific leadership and data processing teams for their wonderful efforts. We appreciate the three extensive and careful reviews that led to a much improved manuscript.

\section{References}

Barrie, L. A., et al. (1988), Ozone destruction and photochemical reactions at polar sunrise in the lower Arctic atmosphere, Nature, 334, 138-141, doi:10.1038/334138a0.

Chance, K. (1998), Analysis of BrO measurements from the Global Ozone Monitoring Experiment, Geophys. Res. Lett., 25, 3335-3338, doi:10.1029/98GL52359.

Chipperfield, M., and D. Kinnison (2010), SPARC CCMVal report on the evaluation of chemistry-climate models, SPARC Rep. 5, edited by V. Eyring, T. G. Shepherd, and D. W. Waugh, chap. 6, World Meteorol. Organ., Geneva, Switzerland.

Garcia, R. R., D. R. Marsh, D. E. Kinnison, B. A. Boville, and F. Sassi (2007), Simulations of secular trends in the middle atmosphere, 19502003, J. Geophys. Res., 112, D09301, doi:10.1029/2006JD007485.

Gettelman, A., and A. H. Sobel (2000), Direct diagnoses of stratospheretroposphere exchange, J. Atmos. Sci., 57, 3-16, doi:10.1175/15200469(2000)057<0003:DDOSTE $>2.0 . \mathrm{CO} ; 2$

Hendrick, F., P. V. Johnston, M. De Mazière, C. Fayt, C. Hermans, K. Kreher, N. Theys, A. Thomas, and M. Van Roozendael (2008), One-decade trend analysis of stratospheric BrO over Harestua $\left(60^{\circ} \mathrm{N}\right)$ and Lauder $\left(45^{\circ} \mathrm{S}\right)$ reveals a decline, Geophys. Res. Lett., 35, L14801, doi:10.1029/ 2008 GL034154.

Hollwedel, J., et al. (2004), Year-to-year variations of spring time polar tropospheric BrO as seen by GOME, Adv. Space Res., 34, 804-808, doi:10.1016/j.asr.2003.08.060. 
Holmes, C. D., D. J. Jacob, and X. Yang (2006), Global lifetime of elemental mercury against oxidation by atomic bromine in the free troposphere, Geophys. Res. Lett., 33, L20808, doi:10.1029/2006GL027176.

Hönninger, G., et al. (2004), Ground-based measurements of halogen oxides at Hudson Bay by active longpath DOAS and passive MAX-DOAS, Geophys. Res. Lett., 31, L04111, doi:10.1029/2003GL018982.

Kleipool, Q. L., M. R. Dobber, J. F. de Haan, and P. F. Levelt (2008), Earth surface reflectance climatology from 3 years of OMI data, J. Geophys. Res., 113, D18308, doi:10.1029/2008JD010290.

Liang, Q., R. S. Stolarski, A. R. Douglass, P. A. Newman, and J. E. Nielsen (2008), Evaluation of emissions and transport of CFCs using surface observations and their seasonal cycles and the GEOS CCM simulation with emissions-based forcing, J. Geophys. Res., 113, D14302, doi:10.1029/ 2007JD009617.

Liao, J., et al. (2010), A comparison of Arctic BrO measurements by chemical ionization mass spectrometery (CIMS) and long path-differential optical absorption spectroscopy (LP-DOAS), J. Geophys. Res., doi:10.1029/2010JD014788, in press.

Liu, A. Q., and G. W. K. Moore (2004), Lake-effect snowstorms over southern Ontario and their synoptic-scale environment, Mon. Weather Rev., 132, 2595-2609, doi:10.1175/MWR2796.1.

McElroy, C. T., C. A. McLinden, and J. C. McConnell (1999), Evidence for bromine monoxide in the free troposphere during the Arctic polar sunrise, Nature, 397, 338-341, doi:10.1038/16904.

Neuman, J. A., et al. (2010), Bromine measurements in $\mathrm{O}_{3}$ depleted air over the Arctic Ocean, Atmos. Chem. Phys., 10, 6503-6514, doi:10.5194/acp10-6503-2010.

Platt, U., and G. Hönninger (2003), The role of halogen species in the troposphere, Chemosphere, 52, 325-338, doi:10.1016/S0045-6535(03) 00216-9.

Richter, A., F. Wittrock, M. Eisinger, and J. P. Burrows (1998), GOME observations of tropospheric BrO in Northern Hemispheric spring and summer 1997, Geophys. Res. Lett., 25, 2683-2686, doi:10.1029/ 98GL52016.

Ridley, B. A., et al. (2007), An ozone depletion event in the sub-Arctic surface layer over Hudson Bay, Canada, J. Atmos. Chem., 57, 255-280, doi:10.1007/s10874-007-9072-z.

Salawitch, R. J. (2006), Biogenic bromine, Nature, 439, 275-277, doi:10.1038/439275a

Salawitch, R. J., D. K. Weisenstein, L. J. Kovalenko, C. E. Sioris, P. O. Wennberg, K. Chance, M. K. W. Ko, and C. A. McLinden (2005), Sensitivity of ozone to bromine in the lower stratosphere, Geophys. Res. Lett., 32, L05811, doi:10.1029/2004GL021504.

Sander, S. P., et al. (2006), Chemical kinetics and photochemical data for use in atmospheric studies, JPL Publ., 06-02.

Schauffler, S. M., E. L. Atlas, D. R. Blake, F. Flocke, R. A. Lueb, J. M. Lee-Taylor, V. Stroud, and W. Travnicek (1999), Distributions of brominated organic compounds in the troposphere and lower stratosphere, J. Geophys. Res., 104, 21,513-21,535, doi:10.1029/1999JD900197.

Simpson, W. R., et al. (2007), Halogens and their role in polar boundarylayer ozone depletion, Atmos. Chem. Phys., 7, 4375-4418, doi:10.5194/ acp-7-4375-2007.

Theys, N., et al. (2009), A global stratospheric BrO climatology based on the BASCOE chemical transport model, Atmos. Chem. Phys., 9, 831-848, doi:10.5194/acp-9-831-2009.

von Glasow, R., et al. (2004), Impact of reactive bromine chemistry in the troposphere, Atmos. Chem. Phys., 4, 2481-2497, doi:10.5194/acp-42481-2004.
Wagner, T., C. Leue, M. Wenig, K. Pfeilsticker, and U. Platt (2001), Spatial and temporal distribution of enhanced boundary layer $\mathrm{BrO}$ concentrations measured by GOME aboard ERS-2, J. Geophys. Res., 106, 24,225-24,235, doi:10.1029/2000JD000201.

Wamsley, P. R., et al. (1998), Distribution of halon-1211 in the upper troposphere and lower stratosphere and the 1994 bromine budget, J. Geophys. Res., 103, 1513-1526, doi:10.1029/97JD02466.

Wernli, H., and M. Sprenger (2007), Identification and ERA-15 climatology of potential vorticity streamers and cutoffs near the extratropical tropopause, J. Atmos. Sci., 64, 1569-1586, doi:10.1175/JAS3912.1.

World Meteorological Organization (WMO) (2007), Global ozone research and monitoring project, in Scientific Assessment of Ozone Depletion: 2006, Rep. 50, World Meteorol. Organ., Geneva, Switzerland.

E. L. Atlas, RSMAS, University of Miami, 4600 Rickenbacker Cwy., Miami, FL 33149, USA.

P. K. Bhartia, A. da Silva, S. Pawson, and J. M. Rodriguez, NASA Goddard Space Flight Center, Code 916, Greenbelt, MD 20771, USA.

D. R. Blake, Department of Chemistry, University of California, 570 Rowland Hall, Irvine, CA 92697, USA.

T. P. Bui, NASA Ames Research Center, Mail Stop 245-5, Moffett Field, CA 94035, USA

T. Canty and R. J. Salawitch, Department of Atmospheric and Oceanic Science, University of Maryland, 2403 Computer and Space Sciences Bldg., College Park, MD 20742, USA. (rjs@atmos.umd.edu)

K. Chance, T. Kurosu, and X. Liu, Harvard-Smithsonian Center for Astrophysics, 60 Garden St., Cambridge, MA 02138, USA.

G. Chen and J. H. Crawford, NASA Langley Research Center, Mail Stop 483, Hampton, VA 23681, USA.

J. E. Dibb, Complex Systems Research Center, University of New Hampshire, Morse Hall, 39 College Rd., Durham, NH 03824, USA.

D. Donohoue and W. R. Simpson, Department of Chemistry and Biochemistry, University of Alaska Fairbanks, Fairbanks, AK 99775, USA

R. S. Gao, B. Johnson, J. A. Neuman, J. B. Nowak, S. Oltmans, and T. B. Ryerson, Earth System Research Laboratory, NOAA, 325 Broadway, Boulder, CO 80305, USA.

F. Hendrick and M. Van Roozendael, Belgian Institute for Space Aeronomy, Ringlaan-3-Avenue Circulaire, B-1180 Brussels, Belgium.

L. G. Huey, J. Liao, R. E. Stickel, and D. J. Tanner, School of Earth and Atmospheric Science, Georgia Institute of Technology, 311 Ferst Dr., Atlanta, GA 30332, USA.

D. J. Jacob, School of Engineering and Applied Sciences, Harvard University, Pierce Hall, 29 Oxford St., Cambridge, MA 02138, USA.

P. V. Johnston and K. Kreher, NIWA, Lauder, Private Bag 50061, Omakau, New Zealand.

D. E. Kinnison, F. Flocke, D. Knapp, D. Montzka, L. L. Pan, S. Tilmes, and A. Weinheimer, National Center for Atmospheric Research, PO Box 3000, Boulder, CO 80305, USA.

Q. Liang, GEST, University of Maryland Baltimore County, Code 613.3, Greenbelt, MD 20771, USA.

J. E. Nielsen, Science Systems and Applications, Inc., 10210 Greenbelt Rd., Ste. 600, Lanham, MD 20706, USA.

R. B. Pierce, NESDIS, NOAA, 1225 West Dayton St., Madison, WI 53706, USA. 